\title{
Differences in ureide and amino acid content of water stressed soybean inoculated with Bradyrhizobium japonicum and B. elkanii
}

\author{
Maria Lucrecia Gerosa Ramos ${ }^{(1)}$, Richard Parsons $^{(2)}$ and Janet Irene Sprent ${ }^{(2)}$
}

(1)Universidade de Brasília, Fac. de Agronomia e Medicina Veterinária, Caixa Postal 04508, CEP 70910-970, Brasília, DF, Brazil. E-mail: lucrecia@unb.br (2)University of Dundee, Biological Sciences, Dundee, DD1 4HN, UK.

\begin{abstract}
The objective of this work was to study the response to water stress of a drought sensitive soybean cultivar inoculated with Bradyrhizobium japonicum (strain CB1809, Semia 586) and B. elkanii (strain 29W, Semia 5019). CB1809 nodulated plants produced a significantly higher root fraction (19\%) than 29W (14.6\%). Plants inoculated with CB1809 produced less nodules and accumulated more nitrogen than those inoculated with 29W. In general, low amounts of ureides in nodules were found in watered plants inoculated with either CB1809 or 29W strains, but those levels were five-fold increased in stressed plants inoculated with CB1809. Nodules formed by strain CB1809 had aspartate and glutamate as major amino acids, while those formed by 29W had glutamate, asparagine and alanine. In nodules of plants inoculated with CB1809 aspartate showed the highest accumulation ( $5 \mu \mathrm{mol} \mathrm{g}$-1); in stressed plants this amino acid reached a value of $26 \mu \mathrm{mol} \mathrm{g}$-1 and asparagine was not detected. Nodules formed by the strain $29 \mathrm{~W}$ accumulated $1 \mu \mathrm{mol} \mathrm{g} \mathrm{g}^{-1}$ of aspartate, whether plants were stressed or not. Asparagine was the major amino acid found in nodules from watered plants $\left(6 \mu \mathrm{mol} \mathrm{g}{ }^{-1}\right)$ and the amount of this amino acid was six-fold increased when plants were water stressed.
\end{abstract}

Index terms: Glycine max, alanine, asparagine, aspartate, glutamate, nitrogen fixation.

\section{Alterações na concentração de ureídos e aminoácidos em soja sob estresse hídrico com inoculação de Bradyrhizobium japonicum e B. elkanii}

\begin{abstract}
Resumo - O objetivo deste trabalho foi estudar a resposta da soja, com inoculação de Bradyrhizobium japonicum (estirpe CB1809, Semia 586) ou B. elkanii (estirpe 29W, Semia 5019), ao estresse hídrico. Plantas com inoculação da estirpe CB1809 produziram maior fração de raízes (19\%) do que aquelas com inoculação de 29W (14,6\%). As plantas com inoculação de CB1809 produziram menos nódulos e acumularam mais nitrogênio do que aquelas com inoculação de 29W. Em geral, baixos teores de ureídos nos nódulos foram encontrados em plantas irrigadas, com inoculação de CB1809 ou 29W, mas esses valores aumentaram cinco vezes em plantas com CB1809, sob estresse hídrico. Os nódulos formados pela estirpe CB1809 produziram, principalmente, aspartato e glutamato, ao passo que aqueles formados pela estirpe 29W produziram mais glutamato, asparagina e alanina. Nos nódulos de plantas com inoculação de CB1809, o aspartato foi o aminoácido que apresentou maior acumulação (5 $\mathrm{mmol} \mathrm{g}^{-1}$ ); em plantas sob estresse hídrico, esse aminoácido alcançou $26 \mu \mathrm{mol} \mathrm{g} \mathrm{g}^{-1}$; e não foi detectada asparagina. Os nódulos formados pela estirpe 29W acumularam $1 \mu \mathrm{mol} \mathrm{g}{ }^{-1}$ de aspartato, em plantas com ou sem estresse. A asparagina foi o principal aminoácido encontrado nos nódulos de plantas irrigadas ( $6 \mu \mathrm{mol} \mathrm{g}$-1); a quantidade desse aminoácido foi aumentada em seis vezes, quando as plantas foram submetidas ao estresse hídrico.
\end{abstract}

Termos para indexação: Glycine max, alanina, asparagina, aspartato, fixação de nitrogênio, glutamato.

\section{Introduction}

The use of inoculants for increasing soybean yield in Brazil is well established. High yields (up to $4000 \mathrm{~kg} \mathrm{ha}^{-1}$ ) can be obtained and, normally, mineral $\mathrm{N}$ is not used. Soybean plants can accumulate up to $40 \%$ of protein in grains, and almost all grain $\mathrm{N}$ is from $\mathrm{N}_{2}$ fixation, representing a $\mathrm{N}$-fertilizer economic benefit that saves over US\$ 2.5 billion per year (Alves et al., 2003). There is a great variability in nodule efficiency among strains of Bradyrhizobium japonicum and B. elkanii; CB1809 is one of the most efficient of them (Dobereiner et al., 1970; Neves et al., 1985; Ramos \& Ribeiro Júnior, 1992).

Neves et al. (1985) distinguished two groups of soybean rhizobial strains for $\mathrm{N}_{2}$ fixation: those with higher efficiency (CB1809, DF 383 and 965) and those with lower efficiency (29W, DF 395 and SM1b). Plants inoculated with the more efficient strains had higher 
ureide content of xylem sap, and higher relative efficiency (less $\mathrm{H}_{2}$ evolved per $\mathrm{N}_{2}$ fixed) than the others. The best strains increased yield by up to $30 \%$. CB1809 strain normally produces few nodules, has high nodule efficiency and high $\mathrm{N}$ accumulation averaged over cultivars, while $29 \mathrm{~W}$ produces a large number of nodules, has low nodule efficiency and low $\mathrm{N}$ accumulation in the plant (Ramos \& Ribeiro Junior, 1992). The superiority of CB1809 has also been confirmed in field experiments (Oliveira et al., 1991).

There are several factors limiting $\mathrm{N}_{2}$ fixation, such as: high temperature, soil acidity (Hungria \& Vargas, 2000) and water stress (Hungria \& Vargas, 2000; Ramos et al., 2003).

Water stress can decrease number and shape of root hairs (Worral \& Roughley, 1976), and when nodules are formed, drought alters nodule structure and weight (Ramos et al., 2003), nitrogenase activity, and synthases of: sucrose, glutamate and glutamine (Ramos et al., 1999).

There are several works showing that soybean cultivars can vary in their capacity of $\mathrm{N}_{2}$ fixation (Bohrer \& Hungria, 1998) and tolerance to water stress (Salinas et al.,1996; Serraj \& Sinclair, 1998; Sinclair et al., 2000). A large variation in nodulation sensitivity to water deficit, among soybean cultivars, can be related to nodule formation and growth (Serraj \& Sinclair, 1998), and soybean genotypes can be selected for $\mathrm{N}_{2}$ fixation and tolerance to water deficits (Sinclair et al., 2000).

It is not known whether soybean plants from the same cultivar, inoculated with contrasting strains can alter its growth and physiological behaviour under water stress.

The aim of this work was to study the effect of water stress on a drought sensitive soybean cultivar inoculated with the strains 29W and CB1809.

\section{Material and Methods}

Seeds of soybean (Glycine max), cultivar Bragg, were surface sterilized in $80 \%$ ethanol for 30 seconds, in $5 \%$ sodium hypochlorite for 2 minutes and then washed ten times in sterilized distilled water. Five days after germination, seedlings were inoculated with either $1 \mathrm{~cm}^{3}$ culture of Bradyrhizobium japonicum (CB1809) or B. elkanii (29W). The strains were obtained from Embrapa Agrobiologia, Seropédica, Brazil.

Each strain was grown in Yeast Extract/Mannitol broth (YEM) (Vincent, 1970) for eight days at $28^{\circ} \mathrm{C}$, on a shaker at $140 \mathrm{rpm}$, and then $1 \mathrm{~cm}^{3}$ containing $2.1 \times 10^{9}$ viable cells was used to inoculate each of the seedlings.
Seeds were planted in Leonard jars (Vincent, 1970), containing a mixture of washed sand and vermiculite $(1: 1 \mathrm{v} / \mathrm{v})$. Jars were previously sterilized by autoclaving at $121^{\circ} \mathrm{C}$ for 1 hour, and then $200 \mathrm{~cm}^{3}$ of nutrient solution (Summerfield et al., 1977) was added. The nutrient solution was prepared in a disinfected container using deionized water. Two seeds per jar were planted and inoculated, and after 5 days they were thinned to one. Sterilized sand was added to the top of the jars in order to avoid cross contamination. Jars with plants without inoculation were grown among inoculated ones, as a control.

Plants were grown in a glasshouse with supplementary light from Phillips SON T lamps giving a quantum irradiance of 500 to $1,000 \mu \mathrm{mol} \mathrm{m}{ }^{-2} \mathrm{~s}^{-1}$ on the top of the plants. The photoperiod was 14 hours, day/night temperatures were $25^{\circ} \mathrm{C}-30^{\circ} \mathrm{C}$ and $15^{\circ} \mathrm{C}-18^{\circ} \mathrm{C}$, respectively; the relative humidity was maintained between $40 \%-50 \%$.

The experimental design was a $2 \times 2$ factorial, with two strains (CB1809 or 29W) and two levels of water supply (water and stress). Jars were arranged in ten randomized blocks. Stress treatment started 25 days after planting, by withholding water from half of the jars. Thirty days after planting, plants were harvested. Half of them were used for chemical analysis and the other half for dry weights and $\mathrm{N}$ content in plant parts. Statistical analyses were made, using ANOVA test.

Leaves were excised and covered immediately with a clean plastic film to avoid dehydration until the water potential was measured in the youngest fully expanded leaf by using a pressure bomb (Scholander et al., 1965). Leaf area was measured using a Delta T meter.

Plant samples were dried in a fan-assisted oven, at $65^{\circ} \mathrm{C}$ for 36 hours. They were then ground in a ball mill to a fine powder and the percentage of $\mathrm{N}$ was determined in 600-800 mg aliquots, using a Carlo Erba Elemental Analyzer (Model 1106), with atropine as standard.

A leaf just below the youngest fully expanded one was excised: part of the leaf was weighed and immediately transferred to a mortar containing $5 \mathrm{~cm}^{3}$ of $400 \mathrm{~mol} \mathrm{~m}^{-3}$ potassium phosphate buffer at $\mathrm{pH}$ 7.0. After grinding, samples were filtered through cotton cloth and immediately placed on ice. They were later transferred to a freezer at $-20^{\circ} \mathrm{C}$. The same procedure was carried out for nodules. Allantoin and allantoic acid were determined colorimetrically following the method of Vogels and Drift (1970), using pure standards from BDH Ltd. 
Parts of the trifoliate leaves were used to quantify amino acids. Samples were weighed and immediately frozen in liquid $\mathrm{N}_{2}$, then they were kept in a freezer at $-20^{\circ} \mathrm{C}$. Approximately $0.5 \mathrm{~g}$ of leaves or nodules were ground with a pestle and mortar in $7.5 \mathrm{~cm}^{3}$ ( $3 \mathrm{~cm}^{3}$ for nodules) of $80 \%$ ethanol acidified with $0.25 \mathrm{~mol} \mathrm{dm}^{-3} \mathrm{HCl}$. Then, $750 \mathrm{~mm}^{3}$ of internal standard ( $2.5 \mathrm{mmol} \mathrm{dm}^{-3}$ nor-leucine) was added, and samples were dried in a rotary evaporator for approximately 20 minutes, at $45^{\circ} \mathrm{C}$. Samples were resuspended in $1 \mathrm{~cm}^{3}$ acidified ethanol and kept overnight in a freezer. Nodule samples were centrifuged twice in an eppendorf centrifuge and kept in a freezer $\left(-20^{\circ} \mathrm{C}\right)$ for 24 hours before analysis.

A standard solution (5 $\mathrm{mm}^{3}$ ) of 18 amino acids (Sigma), each one with a concentration of $2.5 \mathrm{mmol} \mathrm{dm}^{-3}$ was used. Asparagine, glutamine and nor-leucine (as internal standard) were added to the amino acid solutions, giving a final concentration of $2.5 \mathrm{mmol} \mathrm{dm}^{-3}$. Samples were derivatized with phenylisothiocyanate (PITC) to give phenylthiocarbamyl amino acids (Bidlingmeyer et al., 1984). All derivatized samples were kept in freezer $\left(-20^{\circ} \mathrm{C}\right)$ for one or two weeks before running. Analysis was conducted on a Waters HPLC system, using a reverse phase, Nova-Pak $\mathrm{C}_{18}$ column $(3.9 \times 150 \mathrm{~mm})$ at $45^{\circ} \mathrm{C}$, with a gradient of acetate buffer (aqueous phase) and acetonitrile/methanol (organic phase). Amino acids were detected by UV absorbance $(254 \mathrm{~nm})$ and quantified by reference to the internal standard, norleucine. Statistical analyses were made, using ANOVA test.

\section{Results and Discussion}

Rhizobia species had no significant effect on leaf water potential, leaf area or shoot/root ratio (Table 1). Water

Table 1. The effect of rhizobial strain and water stress on leaf water potential (LWP), leaf area (LA) and ratio shoot/root $(\mathrm{S} / \mathrm{R})$ of soybean $^{(1)}$.

\begin{tabular}{lccc}
\hline Treatment & LWP $(\mathrm{MPa})$ & $\mathrm{LA}\left(\mathrm{cm}^{2}\right)$ & $\mathrm{S} / \mathrm{R}$ \\
\hline Strain & & & \\
CB1809 & $-0.99 \mathrm{a}$ & $329 \mathrm{a}$ & $4.16 \mathrm{a}$ \\
29W & $-0.96 \mathrm{a}$ & $303 \mathrm{a}$ & $4.67 \mathrm{a}$ \\
\hline Water & & & \\
Control & $-0.14 \mathrm{~b}$ & $352 \mathrm{a}$ & $4.79 \mathrm{a}$ \\
Stress & $-1.81 \mathrm{a}$ & $278 \mathrm{~b}$ & $4.04 \mathrm{~b}$ \\
\hline PR $>$ F & & $\mathrm{n}$ & $\mathrm{ns}$ \\
Strain (S) & ns & ns & $<0.001$ \\
Water (W) & $<0.001$ & $<0.001$ & ns \\
S x W & ns & ns & \\
\hline
\end{tabular}

(1)Means followed by the same letter in each column do not differ

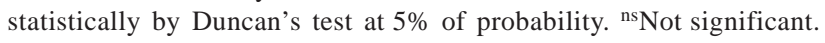

stress significantly decreased leaf water potential, leaf area and shoot/root ratio. There were no significant interactions between strain and stress for those variables.

Nodules from stressed plants had significantly lower total and individual fresh weight (Table 2). There was a highly significant strain and stress interaction for total nodule fresh weight per plant.

Plants inoculated with CB1809 accumulated more N than those with 29W, as found by Neves et al. (1985) and Ramos \& Ribeiro Júnior (1992).

Plants inoculated with $29 \mathrm{~W}$ produced greater nodule dry weight than those inoculated with CB1809, especially when plants were stressed, representing $10 \%$ of total plant weight (Table 3). Plants under water stress, inoculated with CB1809, produced more roots than those inoculated with $29 \mathrm{~W}$.

Total plant dry weight was unaffected by strain (Table 3). Also, no difference was found in nodule dry weight between watered and stressed plants inoculated with CB1809, but 29W had lower nodule dry weight in stressed plants than watered ones (Table 3).

Table 2. The effect of rhizobial strains and water stress on nodule fresh weight (NFW), individual nodule weight (INW), nodule fraction (NF), and total nitrogen in plant of soybean ${ }^{(1)}$.

\begin{tabular}{lcccc}
\hline Treatment & $\begin{array}{c}\text { NFW } \\
\left(\text { g plant }^{-1}\right)\end{array}$ & $\begin{array}{c}\text { INW } \\
(\mathrm{mg})\end{array}$ & $\begin{array}{c}\mathrm{NF}^{(2)} \\
(\mathrm{mg})\end{array}$ & $\begin{array}{c}\text { Total N } \\
(\mathrm{mg})\end{array}$ \\
\hline Strain & & & & \\
CB1809 & $0.80 \mathrm{~b}$ & $2.9 \mathrm{~b}$ & $0.10 \mathrm{~b}$ & $60.57 \mathrm{a}$ \\
$29 \mathrm{~W}$ & $1.00 \mathrm{a}$ & $5.0 \mathrm{a}$ & $0.15 \mathrm{a}$ & $52.76 \mathrm{~b}$ \\
\hline Water & & & & \\
Control & $1.07 \mathrm{a}$ & $1.07 \mathrm{a}$ & $3.90 \mathrm{a}$ & $63.16 \mathrm{a}$ \\
Stress & $0.73 \mathrm{~b}$ & $0.73 \mathrm{a}$ & $0.14 \mathrm{~b}$ & $50.18 \mathrm{~b}$ \\
\hline PR $>$ F & & & & \\
Strain (S) & $<0.001$ & $<0.001$ & $<0.001$ & $<0.05$ \\
Water (W) & $<0.001$ & ns & $<0.001$ & $<0.01$ \\
S x W & $<0.001$ & ns & ns & ns \\
\hline
\end{tabular}

(1)Means followed by the same letter in each row do not differ statistically by Duncan's test at $5 \%$ of probability. ${ }^{(2)}$ Nodule dry weight/whole plant weight. ${ }^{\text {ss }}$ Not significant.

Table 3. Dry weight (g) of watered (W) and water stressed (S) soybean inoculated with Bradyrhizobium japonicum (CB1809) and B. elkanii (29W) ${ }^{(1)}$.

\begin{tabular}{lcccc}
\hline Plant part & CB1809 (W) & CB1809 (S) & $29 \mathrm{~W}(\mathrm{~W})$ & $29 \mathrm{~W}(\mathrm{~S})$ \\
\hline Shoot & $1.75 \mathrm{a}$ & $1.24 \mathrm{~b}$ & $1.65 \mathrm{a}$ & $1.15 \mathrm{~b}$ \\
Root & $0.40 \mathrm{a}$ & $0.32 \mathrm{ab}$ & $0.32 \mathrm{ab}$ & $0.28 \mathrm{~b}$ \\
Nodule & $0.15 \mathrm{c}$ & $0.15 \mathrm{c}$ & $0.22 \mathrm{a}$ & $0.18 \mathrm{~b}$ \\
Total & $2.30 \mathrm{a}$ & $1.71 \mathrm{~b}$ & $2.19 \mathrm{a}$ & $1.61 \mathrm{~b}$ \\
\hline
\end{tabular}

(1)Means followed by the same letter in each row do not differ statistically by Duncan's test at $5 \%$ of probability. 
Low amounts of ureide content were found in nodules from watered plants (Table 4). However, during stress treatment plants inoculated with CB1809 had increased ureide content 3,3 fold, while stressed nodules from 29W had similar amounts in watered plants. Gonzales et al. (1995) also observed an increase in ureides from nodules of stressed soybean (cv. Clark) inoculated with strain RCR3407.

Ureide content in leaves (Table 4) was higher in watered plants inoculated with CB1809, and ureide content was lower in watered plants inoculated with $29 \mathrm{~W}$ and higher in stressed plants. These results suggest that Bradyrhizobium strains had an opposite response when plants were stressed. Rao \& Venkateswarlu (1987) observed an increase of ureide contents in nodules and shoots of two crop legumes (mung bean and moth bean) under water stress, mainly at high levels of stress (between -1.3 and -1.6 MPa). It appears that grain legumes transporting fixed $\mathrm{N}$ as amides, such as chiken pea, faba bean and lupine, are less sensitive to water stress than those transporting ureides, such as soybean.

Amino acids content in nodules and leaves are shown in Tables 5 and 6. In general, nodules formed by CB1809 and 29W showed that different amino acids were produced, depending on strain inoculated (Table 5). Greenwood \& Bathurst (1978) did not find differences in major amino acids extracted from nodules of plants inoculated with nine different $B$. japonicum strains.

Total amount of amino acids in nodules was increased about threefold by stress (Table 5). Nodules formed by strain CB1809 had aspartate and glutamate as the major amino acids, while those formed by $29 \mathrm{~W}$ had glutamate, asparagine and alanine.

In watered plants inoculated with CB1809, aspartate was the amino acid which showed highest accumulation ( $5 \mu \mathrm{mol} \mathrm{g}{ }^{-1} \mathrm{FW}$ ); in stressed plants this amino acid reached values of $26 \mu \mathrm{mol} \mathrm{g}^{-1}$. In watered or stressed nodules asparagine could not be detected. Based on a small peak in that region, asparagine levels were estimated as $<0.8 \mu \mathrm{mol} \mathrm{g}^{-1}$.

Table 4. Ureide content $\left(\mu \mathrm{mol} \mathrm{g} \mathrm{FW}^{-1}\right)$ of watered $(\mathrm{W})$ and water stressed (S) soybean inoculated with Bradyrhizobium japonicum (CB1809) and B. elkanii (29W) ${ }^{(1)}$.

\begin{tabular}{lcccc}
\hline Plant part & CB1809 (W) & CB1809 (S) & 29W (W) & $29 \mathrm{~W}(\mathrm{~S})$ \\
\hline Nodule & $11.52 \mathrm{~b}$ & $38.28 \mathrm{a}$ & $4.96 \mathrm{~b}$ & $7.88 \mathrm{~b}$ \\
Leaf & $12.64 \mathrm{a}$ & $3.76 \mathrm{~b}$ & $3.12 \mathrm{~b}$ & $10.64 \mathrm{a}$ \\
\hline
\end{tabular}

(1)Means followed by the same letter in each row do not differ statistically by Duncan's test at $5 \%$ of probability.
It was possible to estimate the aspartate/asparagine ratio in nodules from plants inoculated with CB1809: in watered plants this ratio was $6: 1$, and in stressed ones ratio was 153:1. In plants inoculated with $29 \mathrm{~W}$ asparagine was the major amino acid in nodules from watered plants ( $6 \mu \mathrm{mol} \mathrm{g}^{-1}$ ), and the amount of this amino acid was increased six fold when plants were stressed. The aspartate/asparagine ratio was 0.15 in watered nodules, and 0.032 in those stressed and inoculated with 29W.

These results suggest that these strains have different metabolism when associated with soybean plants; it is not clear why symbiotic association between strain CB1809 and the plant produces high amounts of aspartate instead of asparagine, and why the symbiotic association between strain $29 \mathrm{~W}$ and the plant produces exactly the opposite (high amounts of asparagine in stressed plants and, in general, low amounts of aspartate).

Asparagine is synthesized by asparagine synthetase and it has been observed that asparagine levels in plant tissues normally increase under stresses such as salt, drought and mineral deficiencies (Ireland, 1990). Miflin \& Lea (1977) suggest that asparagine can act as a temporary store of reduced $\mathrm{N}$, particularly in conditions of carbon limitation, and the plant should be able to synthesize this amino acid in large amounts to avoid $\mathrm{NH}_{4}{ }^{+}$ toxicity. They also suggested that if sufficient fixed carbon is available for amino acid and protein synthesis, asparagine formation should be inhibited. Since the enzyme is present in the plant, bacteria could affect plant ability to synthesize these compounds.

There are several pathways for plant aspartate production. It can be produced by the enzyme aspartase

Table 5. Amino acid content ( $\left.\mu \mathrm{mol} \mathrm{g}^{-1} \mathrm{FW}\right)$ in nodules of watered (W) and water stressed (S) soybean inoculated with Bradyrhizobium japonicum (CB1809) and B. elkanii (29W) ${ }^{(1)}$.

\begin{tabular}{lcccc}
\hline Amino acid & CB1809 $(\mathrm{W})$ & CB1809 (S) & $29 \mathrm{~W}(\mathrm{~W})$ & $29 \mathrm{~W}(\mathrm{~S})$ \\
\hline Aspartate & $4.95 \mathrm{~b}$ & $26.12 \mathrm{a}$ & $0.92 \mathrm{~b}$ & $1.23 \mathrm{~b}$ \\
Glutamate & $3.60 \mathrm{a}$ & $6.28 \mathrm{a}$ & $4.85 \mathrm{a}$ & $5.87 \mathrm{a}$ \\
Serine & $1.06 \mathrm{~b}$ & $2.80 \mathrm{a}$ & $3.42 \mathrm{a}$ & $\mathrm{nd}^{(2)}$ \\
Asparagine & $0.80^{(3)}$ & $0.17^{(3)}$ & $6.19 \mathrm{~b}$ & $38.30 \mathrm{a}$ \\
Glycine & $0.73 \mathrm{a}$ & $0.95 \mathrm{a}$ & $\mathrm{nd}$ & $\mathrm{nd}$ \\
Histidine & $\mathrm{nd}$ & $0.32 \mathrm{a}$ & $\mathrm{nd}$ & $0.61 \mathrm{a}$ \\
Alanine & $0.52 \mathrm{~b}$ & $3.10 \mathrm{ab}$ & $3.10 \mathrm{ab}$ & $5.51 \mathrm{a}$ \\
Proline & $\mathrm{nd}$ & $1.70 \mathrm{a}$ & $\mathrm{nd}$ & $4.28 \mathrm{a}$ \\
Valine & $0.72 \mathrm{~b}$ & $1.89 \mathrm{a}$ & $0.95 \mathrm{~b}$ & $0.26 \mathrm{~b}$ \\
Isoleucine & $\mathrm{nd}$ & $1.68 \mathrm{a}$ & $\mathrm{nd}$ & $0.80 \mathrm{~b}$ \\
Leucine & $\mathrm{nd}$ & $0.98 \mathrm{a}$ & $\mathrm{nd}$ & $0.40 \mathrm{~b}$ \\
Phenylalanine & $\mathrm{nd}$ & $0.24 \mathrm{a}$ & $\mathrm{nd}$ & $0.21 \mathrm{a}$ \\
\hline Total & 12.36 & 46.23 & 19.43 & 57.47 \\
\hline
\end{tabular}

(1)Means followed by the same letter in each row do not differ statistically by Duncan's test at $5 \%$ of probability. ${ }^{(2)}$ Not detected. ${ }^{(3)}$ Estimated values. 
(ammonia assimilating enzyme) or by aspartate dehydrogenase (Ireland, 1990); these enzymes have been detected in few plants, but it appears that they do not have a significant contribution to ammonia assimilation (Ireland, 1990).

Levels of proline increased in stressed nodules from both strains (Table 5). Kohl et al. (1991) observed high amounts of proline in soybean nodules under water stress. They also observed that an increase in P5CR (pyrroline-5-carboxylate reductase - an enzyme related to proline metabolism) activity in nodules was not correlated with drought. This enzyme had an increase of 55\% in stressed 25-day plants, but not in 55-day-old plants. They argued that an increase in P5CR activity in nodules, in response to drought stress, is not necessary for proline accumulation.

Amino acid content in leaves (Table 6) showed, in general, higher values in stressed plants. The concentration of the following amino acids increased in leaves of stressed plants inoculated with CB1809: glutamate, asparagine, threonine, proline, isoleucine, leucine and phenylalanine. In stressed plants inoculated with strain $29 \mathrm{~W}$, levels of asparagine, glycine, glutamine, proline, valine, isoleucine, leucine and phenylalanine increased.

Proline was the amino acid with the highest accumulation in stressed leaves of plants, when they reached $-1.8 \mathrm{MPa}$, representing $21 \%$ and $26 \%$ of the total amino acids detected in plants inoculated with CB1809 and 29W, respectively. Levels of this amino acid can reach up to $58 \%$ of the total amino acids

Table 6. Amino acid content ( $\mu \mathrm{mol} \mathrm{g}{ }^{-1} \mathrm{FW}$ ) in leaves of watered (W) and water stressed (S) soybean inoculated with Bradyrhizobium japonicum (CB1809) and B. elkanii $(29 \mathrm{~W})^{(1)}$.

\begin{tabular}{lcccc}
\hline Amino acid & CB1809(W) & CB1809 (S) & $29 \mathrm{~W}(\mathrm{~W})$ & $29 \mathrm{~W}(\mathrm{~S})$ \\
\hline Aspartate & $0.59 \mathrm{a}$ & $0.98 \mathrm{a}$ & $0.77 \mathrm{a}$ & $0.81 \mathrm{a}$ \\
Glutamate & $0.48 \mathrm{a}$ & $1.33 \mathrm{a}$ & $0.66 \mathrm{~b}$ & $0.98 \mathrm{ab}$ \\
Serine & $0.42 \mathrm{ab}$ & $\mathrm{nd}^{(2)}$ & $0.29 \mathrm{~b}$ & $0.42 \mathrm{ab}$ \\
Asparagine & $\mathrm{nd}$ & $1.48 \mathrm{a}$ & $\mathrm{nd}$ & $1.14 \mathrm{a}$ \\
Glycine & $0.58 \mathrm{~b}$ & $0.91 \mathrm{a}$ & $0.50 \mathrm{~b}$ & $0.92 \mathrm{a}$ \\
Glutamine & $0.60 \mathrm{ab}$ & $0.76 \mathrm{ab}$ & $0.35 \mathrm{~b}$ & $0.97 \mathrm{a}$ \\
Threonine & $\mathrm{nd}$ & 0.83 & $\mathrm{nd}$ & $\mathrm{nd}$ \\
Alanine & $0.52 \mathrm{a}$ & $\mathrm{nd}$ & $0.28 \mathrm{~b}$ & $0.45 \mathrm{ab}$ \\
Proline & $\mathrm{nd}$ & $4.18 \mathrm{a}$ & $\mathrm{nd}$ & $4.68 \mathrm{a}$ \\
Valine & $0.17 \mathrm{a}$ & $1.45 \mathrm{a}$ & $\mathrm{nd}$ & $1.16 \mathrm{a}$ \\
Cysteine & $0.68 \mathrm{ab}$ & $0.26 \mathrm{~b}$ & $0.56 \mathrm{ab}$ & $1.20 \mathrm{a}$ \\
Isoleucine & $0.30 \mathrm{~b}$ & $2.04 \mathrm{a}$ & $\mathrm{nd}$ & $1.47 \mathrm{a}$ \\
Leucine & $\mathrm{nd}$ & $2.71 \mathrm{a}$ & $\mathrm{nd}$ & $2.22 \mathrm{a}$ \\
Phenylalanine & $0.22 \mathrm{c}$ & $2.98 \mathrm{a}$ & $0.20 \mathrm{c}$ & $1.84 \mathrm{~b}$ \\
\hline Total & 4.56 & 19.91 & 3.61 & 18.26 \\
\hline
\end{tabular}

(1)Means followed by the same letter in each row do not differ statistically by Duncan's test at $5 \%$ of probability. ${ }^{(2)}$ Not detected. detected in stressed plants (Ramos, 1996). Proline is known to accumulate in plants under water and salt stress (Fukutoku \& Yamada, 1981); apparently, proline accumulation is a symptom of severe internal water deficit and not an adaptative metabolic response to stress (Hanson \& Hitz, 1983).

An increase of isoleucine, valine and phenylalanine in soybean leaves was also found by Fukutoku \& Yamada (1981) and Ramos (1996). It appears that these amino acids also have a role when plants are kept under water stress.

Amino acid metabolism of plants inoculated with these two strains is apparently different, and this influences amino acid composition of the nodules. Asparagine is synthesised in seeds by asparagine synthetase at germination, when protein reserves are hydrolyzed, or in roots during nitrate assimilation and $\mathrm{N}_{2}$ fixation (Sieciechowicz et al., 1988). An alternative explanation is that these strains, in some way, influence the amino acid metabolism of plant cells.

The diverse efficiency of the symbiotic association produced by these two strains may be related to the different amino acid metabolism of their root nodules, particularly in relation to aspartate and asparagine accumulations.

\section{Conclusions}

1. Plants inoculated with CB1809 produce a higher concentration of ureides in nodules, particularly in stressed plants, than plants inoculated with 29W.

2. Plants inoculated with CB1809 produce more roots than those inoculated with $29 \mathrm{~W}$.

3. Strain CB1809 promotes higher nitrogen accumulation in both stressed and control plants than 29W.

4. Plants inoculated with different strains produce different amounts of amino acids in nodules and leaves.

\section{Acknowledgements}

To Shona McInroy and Irene Geoghegan, for technical assistance; to Dr. Andrea Baker, for supervising the operation of the HPLC; to CNPq, for financial support.

\section{References}

ALVES, B.J.R.; BODDEY, R.M.; URQUIAGA, S. The success of BNF in soybean in Brazil. Plant and Soil, v.252, p.1-9, 2003.

BOHER, T.R.J.; HUNGRIA, M. Avaliação de cultivares de soja quanto à fixação biológica do nitrogênio. Pesquisa Agropecuária Brasileira, v.33, p.937-952, 1998. 
BIDLINGMEYER, B.A.; COHEN, S.A.; TARVIN, T.L. Rapid analysis of amino acids using pre-column derivatization. Journal of Chromatography, v.336, p.93-104, 1984.

DOBEREINER, J.; FRANCO, A.A.; GUZMAN, I. Estirpes de Rhizobium de excepcional eficiência. Pesquisa Agropecuária Brasileira, v.5, p.155-161, 1970.

FUKUTOKU, Y.; YAMADA, Y. Sources of proline-nitrogen in water-stressed soybean (Glycine max L.). I. Protein metabolism and proline accumulation. Plant Cell Physiology, v.22, p.1397-1404, 1981.

GONZALES, E.M.; GORDON, A.J.; JAMES, C.L.; ARRESEIGOR, C. The role of sucrose synthase in the response of soybean nodules to drought. Journal of Experimental Botany, v.46, p.15151523, 1995.

GREENWOOD, R.M.; BATHURST, N.O. Effect of rhizobia strain and host on the amino acid pattern in legume root nodules. New Zealand Journal Science, v.21, p.107-120, 1978.

HANSON, A.D.; HITZ, W.D. Whole-plant response to water deficits: water deficits and the nitrogen economy. In: LIMITATIONS to efficiency water use in crop production. Madison: ASA-CSSASSSA, 1983. p.331-343.

HUNGRIA, M.; VARGAS, M.A.T. Environmental factors affecting $\mathrm{N}_{2}$ fixation in grain legumes in the tropics, with emphasis on Brazil. Field Crop Research, v.65, p.151-164, 2000.

IRELAND, R. Amino acid and ureide biosynthesis. In: DENNIS, D.T.; TURPIN, D.H. (Ed.). Plant physiology, biochemistry and molecular biology. London: London Scientific Technical, 1990. p.406-421.

KOHL, D.H.; KENNELLY, D.J.; ZHY, Y.; SCHUBERT, K.R.; SHEADER, G. Proline accumulation, nitrogenase $\left(\mathrm{C}_{2} \mathrm{H}_{2}\right.$ reducing) activity and activities of enzymes related to proline metabolism in drought-stressed soybean nodules. Journal of Experimental Botany, v.42, p.831-837, 1991.

MIFLIN, B.J.; LEA, P. Amino acid metabolism. Annual Review of Plant Physiology, v.28, p.299-329, 1977.

NEVES, M.C.P.; DIDONET, A.D.; DUQUE, F.F.; DOBEREINER, J. Rhizobium strains effects on nitrogen transport and distribution in soybean. Journal of Experimental Botany, v.36, p.1179-1192, 1985.

OLIVEIRA, J.C.; RAMOS, M.L.G.; DUQUE, F.F. Inoculação da soja, em solo de cerrado no primeiro ano de cultivo. Revista Brasileira de Ciência do Solo, v.15, p.273-276, 1991.

RAMOS, M.L.G. Physiological responses of crop legumes to water stress. 1996. 230p. Thesis (Ph.D.) - University of Dundee, Scotland.
RAMOS, M.L.G.; RIBEIRO JUNIOR, W.Q. Especificidade hospedeira entre estirpes de Bradyrhizobium japonicum e genótipos de soja com ciclo de maturação tardio. Pesquisa Agropecuária Brasileira, v.27, p.259-263, 1992.

RAMOS, M.L.G.; GORDON, A.J.; MINCHIN, F.R.; SPRENT, J.I.; PARSONS, R. Effect of water stress on nodule physiology and biochemistry of a drought tolerant cultivar of common bean (Phaseolus vulgaris L.). Annals of Botany, v.83, p.57-63, 1999.

RAMOS, M.L.G.; PARSONS, R.; SPRENT, J.I.; JAMES, E.K. Effect of water stress on nitrogen fixation and nodule structure of common bean. Pesquisa Agropecuária Brasileira, v.38, p.339347, 2003.

RAO, A.V.; VENKATESWARLU, B. Nitrogen fixation as influenced by water stress in selected crop legumes of the Indian arid zone. Arid Soil Research and Rehabilitation, v.1, p.89-96, 1987.

SALINAS, A.R.; ZELENER, N.; CRAVIOTTO, R.M.; BISARO, V. Respuestas fisiológicas que caracterizan el comportamiento de diferentes cultivares de soja a la deficiencia hidrica en el suelo. Pesquisa Agropecuária Brasileira, v.31, p.331-338, 1996.

SCHOLANDER, P.F.; HAMMEL, H.T.; BRADSTREET, E.D.; HEMMINGSEN, E.A. Sap pressure in vascular plants: negative hydrostatic pressure can be measured on plants. Science, v.148, p.339-346, 1965.

SERRAJ, R.; SINCLAIR, T.R. Soybean cultivar variability for nodule formation and growth under drought. Plant and Soil, v.202, p.159166, 1998.

SIECIECHOWICZ, K.A.; JOY, K.W.; IRELAND, R.J. The metabolism of asparagine in plants. Phytochemistry, v.27, p.663671, 1988

SINCLAIR, T.R.; PURCELL, L.C.; VALDEZ, V.; SERRAJ, R.; KING, A.; NELSON, R. Identification of soybean genotypes with $\mathrm{N}_{2}$ fixation tolerance to water deficits. Crop Science, v.40, p.18031809, 2000.

SUMMERFIELD, R.J.; HUXLEY, P.A.; MINCHIN, F.R. Plant husbandry and management techniques of growing grain legumes under simulated tropical conditions in controlled environments. Experimental Agriculture, v.13, p.81-92, 1977.

VINCENT, J.M. A manual for the practical study of root-nodule bacteria. Oxford: Blackwell, 1970.

VOGELS, G.D.; DRIFT, D. van der. Differential analysis of glyoxylate derivatives. Annals of Biochemistry, v.33, p.143-157, 1970

WORRAL, V.S.; ROUGHLEY, R.J. The effect of moisture stress on infection of Trifolium subterraneum L. by Rhizobium trifolii Dang. Journal of Experimental Botany, v.27, p.1233-1241, 1976.

$\overline{\text { Received on March 25, } 2004 \text { and accepted on December 7, } 2004}$ 